\title{
ALICANTE COASTAL MANAGEMENT FOR SUSTAINABLE DEVELOPMENT
}

\author{
I. LÓPEZ ${ }^{1}$, L. ARAGONÉS ${ }^{1}$, Y. VILLACAMPA ${ }^{2}$, L. BAÑÓN ${ }^{1} \&$ A. PALAZÓN ${ }^{3}$ \\ ${ }^{1}$ Department of Civil Engineering, Alicante University, Spain. \\ ${ }^{2}$ Department of Applied Mathematics, Alicante University, Spain. \\ ${ }^{3}$ Department of Civil Engineering, Catholic University of Murcia, Spain.
}

\begin{abstract}
Human intervention on the coast has been intense, due to the source of wealth that the coastal areas represent, especially in the form of tourism, which has resulted in a rapid erosion of its beaches. This paper discusses the current state of beach management in the various competent public administrations on the Costa Blanca (SE Spanish-Mediterranean), in relation to urban development and regression on the waterfront. To this end, an analysis has been carried out of the responses to a survey of those responsible for managing each of the 19 coastal municipalities of the Alicante coast, covering $244 \mathrm{~km}$ of coastline, 91 beaches and their personnel. Also, an investigation has been conducted as to whether this management's aim is to protect the coastline and maintain the flora and fauna or just to manage recreation as the main economic activity is tourism. The analysis shows that the beach is simply regarded as a product or service offered to the user thereof. However, local authorities have not detected problems, possibly for two reasons: they do not have sufficient knowledge and this is understandable, given their lack of responsibilities in this area. This causes many beaches to have a high occupancy rate and there is a shift of users towards natural beaches. The study gives us information about the complex administrative process in the coastal system that often proves ineffective on this narrow strip of land. Keywords: beach erosion, investment, management of beaches, sand and gravel, urban and natural beaches.
\end{abstract}

\section{INTRODUCTION}

Beaches make up 24\% of the Spanish coast, and much of this space is under great pressure to settle large urban population centres around it. Administrative and maintenance management schemes for beaches in Spain are very complex because in many cases the powers are exchanged between administrations [1].

Grumbine [2] compiled a summary of the main objectives to be pursued by any action on a specific area within environmental management. These objectives are five in number: (i) to maintain the population of the species in their ecosystems; (ii) to study and define the areas in which the different ecosystems integrated in the study area are developed; (iii) to maintain the ecological and evolutionary processes of these ecosystems; (iv) to take into account the time scale of conditions that can lead to a specific action on existing ecosystems and (v) to integrate human use within that ecosystem with a number of restrictions.

For the proper management of a coastal system, four basic points, to be jointly developed by the competent bodies, are established; based on their development, an appropriate balance between available resources and their use was derived [3]. These four main points are: Analysis, Planning, Management and Monitoring. Theoretically, responsibilities in the field of coastal management are divided into three tiers (Costas Law 2/2013): Central 
Administration, (ii) Regional Administration and (iii) Local Administration. The first deals with the management of the coastal public domain, the second with management planning land use. The municipalities, with limited authority, are responsible for maintaining and providing the necessary services, experiencing despite their limitations, most of the benefits and problems associated with the presence of beaches. A crucial problem in the management of costs, as already remarked, is the fact that competence in coastal matters is diversified among different organisms that are usually uncoordinated [4]. Beach managers should pay particular attention to developments (regression/accretion) [5].

Currently, coastal erosion has reached a disproportionate value: about $70 \%$ of the coastline is being eroded [6]. Erosion can serve [7, 8] as justification for the development of vulnerability indices and coastal risk analysis procedures to help coastal planners, managers, engineers and developers to carry out their professional responsibilities in the treatment of the right to answers to future climate change [7]. A practical means for controlling beaches is through the daily maintenance work carried out by local authorities, since through a series of standardized activities, they could warn of the most common problems and notify their existence to the entities responsible for dealing with these problems [1].

However, although important, it is not only the evolution of the beaches, which has influenced the management thereof. There are more elements to consider. The perception of beach users is directly related to hygiene, functional and safety factors. The demand for space to sunbathe and relax is the main use to which a beach is put, so the beaches are mostly seen as playgrounds [4].

This paper seeks to determine how the beaches of the Alicante coast are managing and how the problems thereof are undertaken, or not, by the different administrations in charge of their management. This is performed by analysing the type of management, depending on the level of urbanization of the beach (urban, semi-urban or natural), and the type of sediment that it is compose of (sand or gravel). To do this, surveys of those responsible for the management and organization of the beaches of the 19 coastal municipalities in the province will be used; the identified problems will be analysed, as well as their importance and the type of management undertaken to solve them.

\section{STUDY AREA}

The study area is located in the province of Alicante, which lies on the southeast coast of the Iberian Peninsula, being the southernmost and least extensive of Valencia (25\% of its territory) province. It is characterized by its coastline of cliffs and rocky bottoms. The cliffs sometimes reach $300 \mathrm{~m}$ in height; however, its southern coast is low and sandy, with frequent bays and lagoons, and dune ridges in many of its beaches [9].

Alicante has $244 \mathrm{~km}$ of coastline, along which 91 beaches are found, of which 30 are of gravel and 61 of sand, distributed among 19 municipalities; see Fig. 1.

Due to the favourable configuration of beaches, most of the coast is urbanized and presents a major urban and tourist pressure, hosting $59.2 \%$ of the population of the province. The most populated municipalities are those of Alicante and Benidorm, and the least populated is Benitatxell. Orihuela has the highest number of beaches and Jávea the longest coastline. The coast has 27 marinas, one port of general interest (Alicante) and two others (Dénia and Torrevieja) (Chamber of Commerce, Industry and Navigation, 2012).

\section{METHODOLOGY}

This study was supported by surveys conducted for each coastal town of Alicante as well as in-depth study of the physical, sociological and economic characteristics of the environment and a historical evolution of the coastline. 


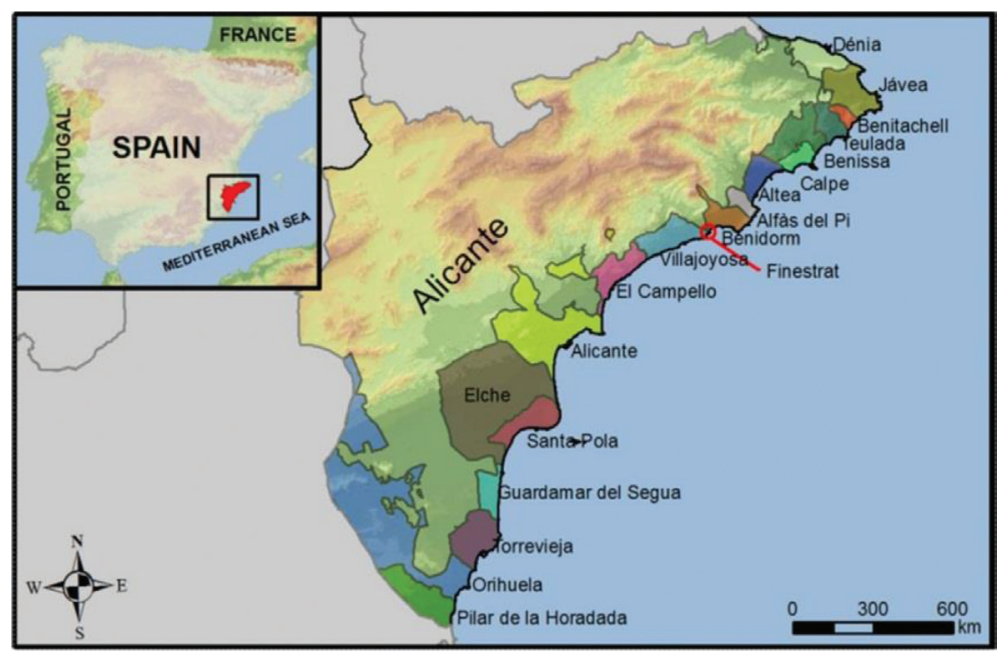

Figure 1: Municipalities of the coast of Alicante.

\subsection{Surveys}

A survey was carried out in all administrations in the province of Alicante which have jurisdiction over the management and maintenance of the beaches to make an individualized study of how each one of them has led the identification of problems and how to tackle them in each. For their study, the beaches have been classified as urban, semi-urban and natural, following the studies of Ariza et al. [1]. This classification was completed with another, according to the characteristics of the deposited material, distinguishing between sand, gravel or mixed beaches [10].

The survey was analysed by dividing the data into three groups according to their relationship with: (i) functional beach in terms of coastal protection; (ii) user-oriented beach management: quality marks, recognized occupation and capacity, and quality of water; (iii) investment. For each analysed variable, the following points are evaluated: (1) provision of blue flag; (2) quality distinctive ISO (International Organization for Standardization); (3) times of high density; (4) erosion problems; (5) regeneration processes (material); (6) algae, treatments, cleaning; (7) defence elements (types); (8) effects of marine works; (9) specific departments to manage; (10) outsourcing services; (11) managers' degrees; (12) number of departments responsible, and (13) total investment.

Finally, the survey evaluated: (1) beach cleaning; (2) the quality of water and sand; (3) protection of ecosystems from the beach; (4) the problems of beach erosion; (5) massive densification; (6) treatment of plagues of jellyfish; (7) quality of access to the beach; (8) safety (rescue and police), and (9) recreational activities offered on beaches.

\subsection{Physical and socioeconomic characteristics}

The data regarding the physical characteristics of the beaches (sediment type and length) were obtained from [10]. As for the socioeconomic features (population, labour force, hotel rooms and car park), this information was obtained from the Government of Alicante. 


\subsection{Evolution of the coastline}

For this study, the variations in the widths and surfaces of beaches for the period from 1981 to 2014 were analysed. To do this, frames and orthophotos were used, the former have been georeferenced using the ArcGIS. The line of the last wet water mark on the beach profile has been selected as the criterion for the digitalization of the coastline [11].

To consider artificial regenerations carried out in each of the beaches, the beach area representing each nourishment has been subtracted from the surface present on the beach that year. The CUR's formula [12] was used to determine the beach area provided by each nourishment. For other years, its evolution has been obtained as the difference between the anterior and posterior years and from the result of measurements. Finally, we have grouped the results of the rate of evolution into two periods: 1981-2005 and 2005-2014.

\section{RESULTS}

The surface and length obtained for each of the 19 coastal municipalities of the province of Alicante can be observed in Table 1. Of the 91 beaches surveyed, it was found that $67 \%$ are sand and $33 \%$ are gravel (Table 1).

Regarding the degree of urbanization it is seen as the most sand beaches are urban (65.5\%), though most natural beaches of gravel (23.4\%) (Fig. 2).

Table 1: Indicators of the different municipalities analysed in the study.

\begin{tabular}{|c|c|c|c|c|c|c|c|}
\hline & \multirow{2}{*}{$\begin{array}{l}\text { Surface } \\
\left(\mathbf{k m}^{2}\right)\end{array}$} & \multirow{2}{*}{$\begin{array}{l}\text { Coast } \\
\text { length } \\
(\mathbf{k m})\end{array}$} & \multirow{2}{*}{$\begin{array}{l}\text { Sand } \\
\text { beaches }\end{array}$} & \multirow{2}{*}{$\begin{array}{l}\text { Gravel } \\
\text { beaches }\end{array}$} & \multirow[b]{2}{*}{ Population } & \multicolumn{2}{|c|}{ Hotel } \\
\hline & & & & & & Number & Rooms \\
\hline Dénia & 66.2 & 19 & 7 & 2 & 41,672 & 330 & 2,356 \\
\hline Jávea & 68.6 & 25 & 2 & 5 & 29,067 & 13 & 978 \\
\hline Benitatxell & 12.7 & 2 & 0 & 1 & 4,659 & 5 & 104 \\
\hline Teulada & 32.2 & 8 & 3 & 1 & 11,824 & 23 & 289 \\
\hline Benissa & 69.7 & 4 & 1 & 1 & 11,572 & - & - \\
\hline Calpe & 23.5 & 11 & 3 & 1 & 22,437 & 94 & 3,429 \\
\hline Altea & 34.4 & 7 & 0 & 7 & 22,518 & 133 & 1,398 \\
\hline Alfàs del Pí & 19.3 & 4 & 0 & 1 & 21,357 & 151 & 2,202 \\
\hline Benidorm & 38.5 & 10 & 2 & 0 & 69,010 & 131 & 40,236 \\
\hline Finestrat & 42.6 & 2 & 1 & 0 & 6,265 & 5 & 523 \\
\hline Villajoyosa & 59.3 & 15 & 1 & 7 & 33,951 & 4 & 706 \\
\hline Campello & 55.3 & 23 & 4 & 4 & 27,081 & 8 & 535 \\
\hline Alicante & 201.3 & 23 & 3 & 0 & 332,067 & 50 & 7,237 \\
\hline Elche & 326.1 & 12 & 3 & 0 & 228,647 & 19 & 1,745 \\
\hline Santa pola & 58.2 & 15 & 7 & 0 & 31,529 & 5 & 712 \\
\hline Guardamar & 35.6 & 14 & 5 & 0 & 15,599 & 10 & 1,691 \\
\hline Torrevieja & 71.4 & 14 & 5 & 0 & 91,415 & 14 & 1,660 \\
\hline Orihuela & 365.4 & 10 & 8 & 0 & 83,417 & 6 & 908 \\
\hline Pilar de Horadada & 77.9 & 5 & 6 & 0 & 21,588 & 3 & 127 \\
\hline
\end{tabular}




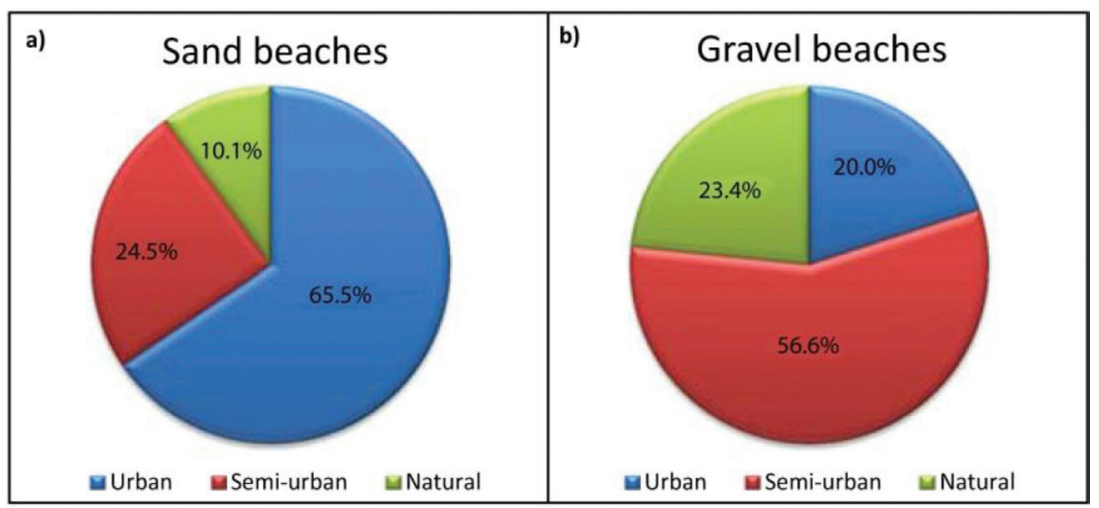

Figure 2: Percentage of urban, semi-urban and natural beaches. a) Sand beaches. b) Gravel beaches

The investment made by the municipalities has been analysed in terms of: (i) the number of managed beaches (Fig. 3a), showing a great disparity in the results, with Teulada and Torrevieja being the municipalities with the highest investment per number of beaches and Elche the least; (ii) the length of coastline of each municipality (Fig. 3b); in this case Benitaxell would be the one with the largest investment, followed by El Campello and Alicante; (iii) the surface of beaches; Fig. $3 \mathrm{c}$ shows that the investment is higher in small beaches, whether gravel or sand; (iv) the level of urbanization (Fig. 3d), whence it follows that the natural beaches receive more investment than their urban or semi-urban counterparts, and (v) the number of departments dedicated to managing the beach in each municipality (Fig. 3e and f), from which it follows that $33 \%$ of municipalities have a single department dedicated to the management of the beach, $22 \%$ have two departments, $9 \%$ have three, $13 \%$ have four, and $1 \%$ has five departments However, no direct relationship between the number of departments and investment is observed.

Comparing investments with existing hotel rooms, it is seen that, in Teulada where there is a greater investment and in Elche where there is less, this does not correspond to the number of hotel rooms, which is high in Benidorm and minimal in Benitatxell (Fig. 3g).

In addition, the qualifications of those responsible, as well as the number of employees by department, have been analysed (Fig. 4). The study shows that the subject in which the largest number of managers graduated is biology, with lawyers and technical engineers being poorly represented (Fig. 4a). As the number of employees, no relationship is observed, since there are two workers for two departments or three workers for one department (Fig. 4b).

Finally, with regard to the evolution of the coast by municipalities, almost widespread declines are observed, being the biggest in the town of Benissa both gravel and sand beaches (Table 2). On knowledge of this process by the managers of the municipalities, it is clear from the survey that has knowledge of the state of erosion/accretion, although they have not quantified. This knowledge in the case of sandy beaches would be $22.5 \%$ in urban areas, $33.33 \%$ in semi-urban and $50 \%$ in natural, while the gravel beaches ignorance about evolution is almost complete. To the knowledge of the managers $38 \%$ of sandy beaches are eroding and have not been regenerated or treated, while $55 \%$ of sandy beaches have been regenerated (Fig. 5). 


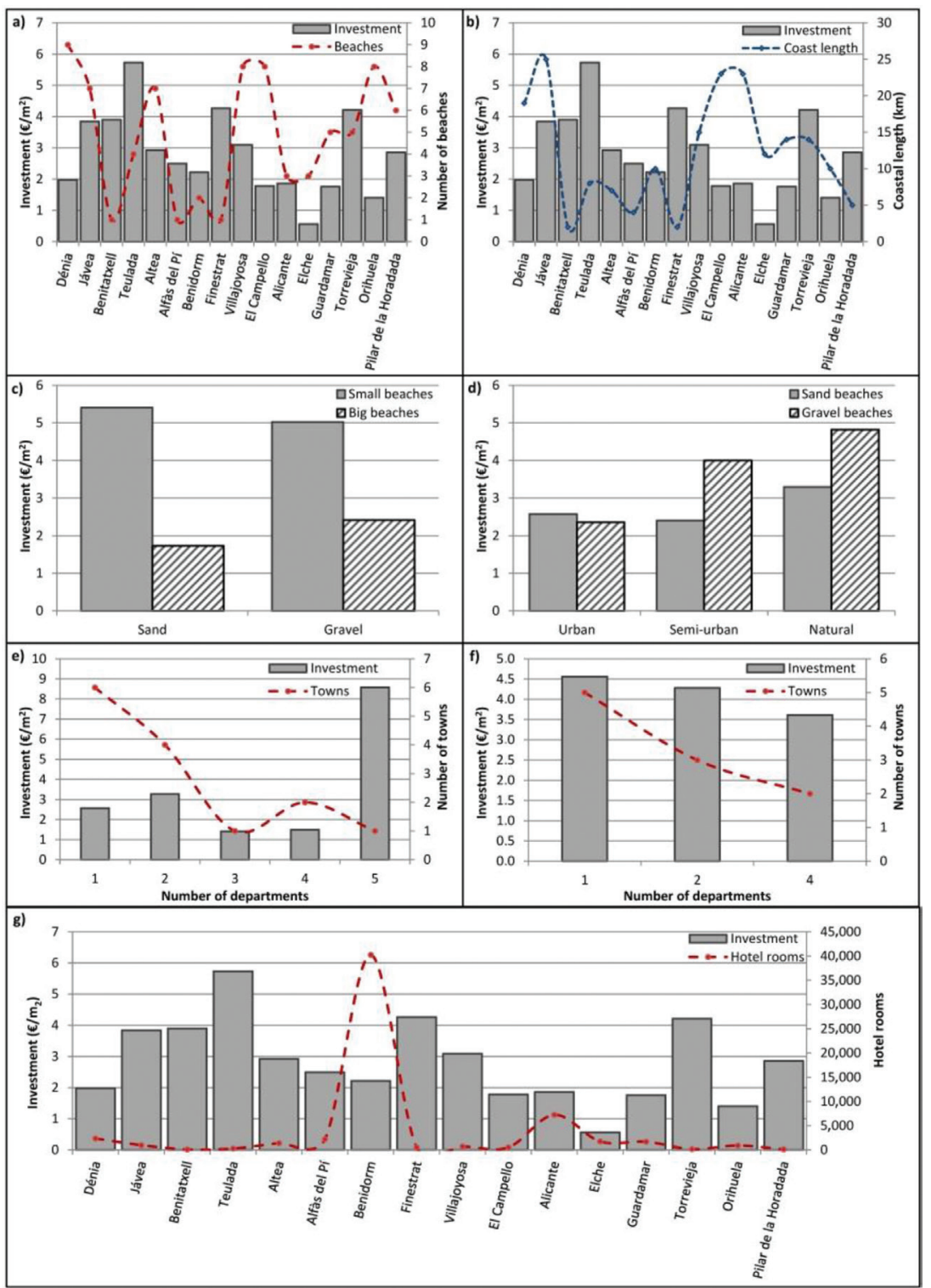

Figure 3: Mean investment with respect to: the number of beaches by town (a), the length of coastline per municipality (b), the size of the beaches (c), the level of urbanization (d), the number of departments for sand (e) and gravel beaches (f) and the hotel rooms $(\mathrm{g})$.

\section{DISCUSSION}

Given the importance of the beaches on the coast of the province of Alicante, not only for their help in protecting the coast itself but also for their contribution to the wealth of the area that coastal tourism produces in the service sector, management is fundamental. Therefore, better management is expected in beaches located in major population centres. From the study of management, use and exploitation can be reconciled with environmental beach 
340 Urban Regeneration and Sustainability

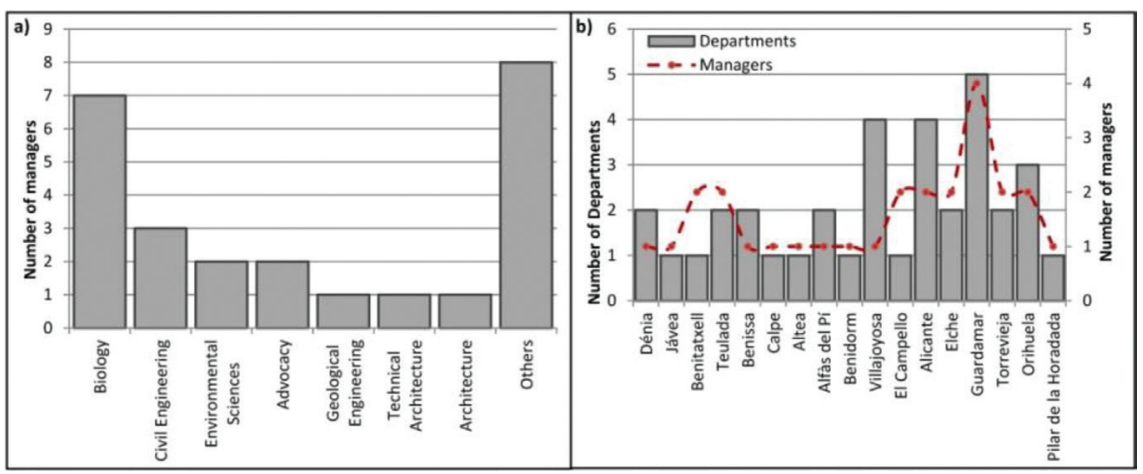

Figure 4: (a) Number of managers and professional qualifications (b) Number of managers in relation to the number of departments.

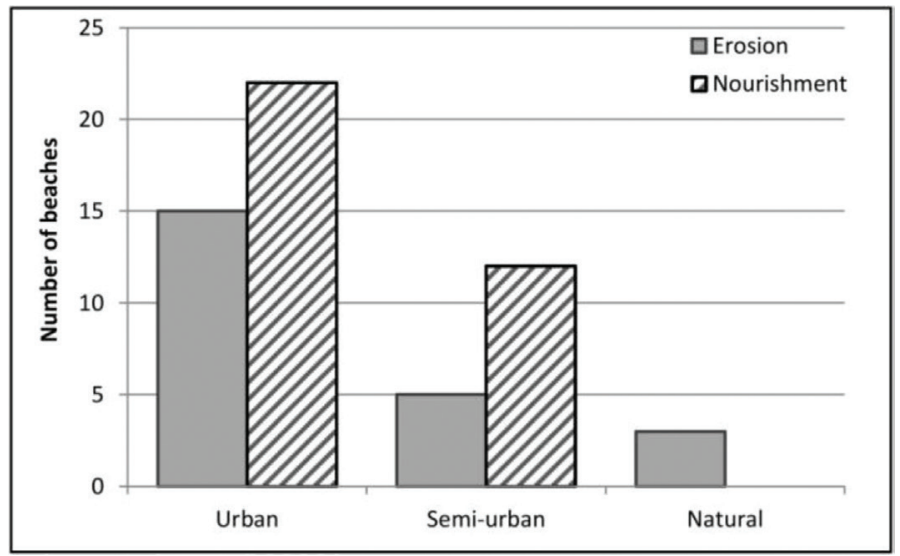

Figure 5: Number of eroding and nourished sand beaches according to the level of urbanization of the environment.

maintenance. The result will be the satisfaction of all stakeholders, social and economic benefits and, especially, a good legacy for new generations.

In the analysis of the coast of Alicante, as a first observation, the urban or semi-urban character of most of the beaches is obtained, indicating a coast with few natural spaces because of the great development that the coast has suffered (Fig. 2). The distribution of the type of beach also corresponds to the geomorphology of the coast. The gravel beaches are concentrated between Dénia and El Campello, while most of the sandy beaches are found in the southern part of the province that corresponds to a low and sandy coast with dune ridges and coastal lagoons.

When checking the investments made by the various municipalities, no relation is observed regarding: the number of beaches (Fig. 3a) or the length of the beach, as there are municipalities such as Campello or Alicante with longer coastlines than other municipalities (e.g. Torrevieja or Villajoyosa) and yet the investment $/ \mathrm{m}^{2}$ is lower (Fig. 3b). However, small beaches receive the largest investments (Fig. 3c). Also, gravel beaches and more specifically natural ones have more investment $/ \mathrm{m}^{2}$ (Fig. 3d). This may be due to: i) the greatest distance to the city centre; ii) gravel beaches require manual cleaning, and iii) the complexity of access to many 
Table 2: Rates of evolution of the coastal municipalities.

\begin{tabular}{|c|c|c|c|c|}
\hline \multirow[b]{2}{*}{ Municipality } & \multicolumn{2}{|c|}{ Sand beaches } & \multicolumn{2}{|c|}{ Gravel beaches } \\
\hline & $\begin{array}{c}\text { m/year } \\
\text { 1981-2005 }\end{array}$ & $\begin{array}{c}\text { m/year } \\
2005-2014\end{array}$ & $\begin{array}{c}\text { m/year } \\
\text { 1981-2005 }\end{array}$ & $\begin{array}{c}\text { m/year } \\
2005-2014\end{array}$ \\
\hline Dénia & -0.36 & -0.62 & 0.19 & -0.07 \\
\hline Jávea & 0.10 & -0.01 & -0.14 & -0.30 \\
\hline Benitatxel & - & - & -0.14 & -0.18 \\
\hline Teulada & -0.42 & -0.73 & -0.35 & -0.27 \\
\hline Benissa & -1.04 & -0.14 & -0.82 & -0.05 \\
\hline Calpe & -0.20 & -0.67 & -0.13 & -0.18 \\
\hline Altea & - & - & -0.19 & -0.16 \\
\hline Alfàs del Pí & - & - & 0.12 & -0.09 \\
\hline Benidorm & -1.11 & -0.36 & - & - \\
\hline Finestrat & 0.15 & -0.41 & - & - \\
\hline Villajoyosa & 1.41 & -0.47 & -0.05 & -0.30 \\
\hline El Campello & -0.74 & 0.22 & -0.18 & -0.24 \\
\hline Alicante & -0.57 & 0.06 & - & - \\
\hline Elche & -0.08 & -0.27 & - & - \\
\hline Santa Pola & -0.53 & 0.05 & - & - \\
\hline Guardamar & 0.27 & -0.91 & - & - \\
\hline Torrevieja & -0.07 & -0.52 & - & - \\
\hline Orihuela & 0.08 & -0.51 & - & - \\
\hline Pilar de la Horadada & -0.30 & -1.04 & - & - \\
\hline
\end{tabular}

of these beaches. Moreover, there are towns like Dénia, Jávea, Teulada, Villajoyosa and Altea where most beaches are gravel (Table 1), which may distort the investment percentage, when compared with the rest of the province. If the investment is compared with the number of hotel rooms, there is also no relationship observed (Fig. 3g). When the number of departments is related to investment $\left(€ / \mathrm{m}^{2}\right)$, there is no clear relationship between them (Fig. 3e and $\mathrm{f}$ ).

Given that the highest concentration of hotels and services are in urban beaches, it seems logical that the managers have been worried about this; basically, they are most concerned about acquiring space for recreational use in the short term and having to optimize always scarce resources. This has led to any natural beach being regenerated, even knowing that $50 \%$ of them have some kind of problem, as is clear from the replies of the managers (Fig. 5). This is logical in a community like Valencia, where the beaches are one of the great engines of the economy and therefore investments go toward beaches which enjoy greater use.

However, if the balance is broken on a beach, producing an erosion process, those in local government should understand all these factors that have changed the balance of the beach in order to act and maintain the coastline, as this is the defence between the sea and the land. But, as noted, local governments ignore these factors in depth, as well as the movement of the 
coastline. Only the manager of the Tiestos beach in Benitatxell said he had knowledge of a localized problem of erosion, but he did not know to what cause it could be attributed. In the data from the rest of the beaches, respondents did not answer these questions. Although the Municipal Administration is not responsible for the maintenance, it is true that it has the greatest knowledge about the beach and presence there, because of its constant contact, through the cleaning work and care of the area. One possible reason can be seen in the profile of municipality beach managers; as evidenced, most are technicians with little knowledge in maritime engineering, given the subject of their degree (Fig. 4a); therefore their ignorance in this area is clear. The problem is further complicated when we consider that, in some municipalities, the same management is responsible for various departments (Fig. 4b).

Studies show a continuing state of regression on the beaches of the province of Alicante (Table 2), of which their managers are completely unaware. While it is true that they are not responsible for maintaining the waterfront, they are responsible for the maintenance and services required, as well as for troubleshooting on its beaches. From the study, the complete discretion of each local government in terms of money for the continuation of its beaches is clear, since there is no correlation between this and any of the variables analysed. This shows the lack of coordination between the different administrations.

\section{CONCLUSION}

A sustainable coastal city cannot be achieved without adequate management of its coasts and beaches, as in any other part of the city. To do this, all actors involved should be organized so that the detected problems can be solved. As is clear from the study conducted, this does not occur in the towns of Alicante, showing a lack of coordination between the managers which derives from an error of law that regulates and distributes the competences that each Administration has on the coast. Management should not only be oriented to the cleaning and maintenance of surfaces and the services demanded by users but also to the knowledge and resolution of various problems such as erosion, the maintenance of natural areas and the integration of the beach into the city. However, it has been found that there is total ignorance on the part of the majority of managers.

In addition, it can be seen that investment in the maintenance of the beaches does not correspond to the idea of sustainable management; it is rather short-term oriented and provides a service to users, mainly tourists. No relationship was observed between investment and the various factors analysed (number of beaches, beach length, type of sediment from the beach, number of hotel rooms, number of departments, etc.). Failure to adapt resources to the real needs of the beaches impedes the steps taken to obtain optimal results.

Therefore, municipal managers should collect information and coordinate actions with other governments (state or central) to conduct specialized management. This takes into account the characteristics of each area in order to meet the needs of users without compromising the ability of future users to meet their needs, seeking a balance between economic and environmental issues. To this end, the organization of available resources is essential for achieving sustainable cities and beaches.

\section{REFERENCES}

[1] Ariza, E., Jiménez, J. \& Sardá, R., A critical assessment of beach management on the Catalan coast. Ocean \& Coastal Management, 51(2), pp. 141-160, 2008.

http://dx.doi.org/10.1016/j.ocecoaman.2007.02.009 
[2] Grumbine, R.E., What is ecosystem management? Conservation Biology, 8(1), pp. 27-38, 1994.

http://dx.doi.org/10.1046/j.1523-1739.1994.08010027.x

[3] Micallef, A. \& Williams, A.T., Theoretical strategy considerations for beach management. Ocean \& Coastal Management, 45(4-5), pp. 261-275, 2002. http://dx.doi.org/10.1016/S0964-5691(02)00058-3

[4] Breton, F., Clapés, J., Marquès, A. \& Priestley, G.K., The recreational use of beaches and consequences for the development of new trends in management: the case of the beaches of the Metropolitan Region of Barcelona (Catalonia, Spain). Ocean \& Coastal Management, 32(3), pp. 153-180, 1996. http://dx.doi.org/10.1016/S0964-5691(96)00032-4

[5] Salman, A., Lombardo, S. \& Doody, P., Living with coastal erosion in Europe: sediment and space for sustainability, EUCC, 2004.

[6] Bird, E.C.F., Coastline Changes. A Global Review, New York: John Wiley and Sons, p. 219, 1985.

[7] Hughes, P. \& Brundrit, G., An index to assess South Africa's vulnerability to sea-level rise. South African Journal of Science, 88(6), pp. 308-311, 1992.

[8] Jelgersma, S., Van der Zijp, M. \& Brinkman, R., Sealevel rise and the coastal lowlands in the developing world. Journal of Coastal Research, 9, pp. 958-972, 1993.

[9] ECOLEVANTE, Estudio ecocartográfico de las provincias de Valencia y Alicante, ed. D.G.d. Costas, Ministerio de Medio Ambiente, 2006.

[10] MAGRAMA, Ministerio de Agricultura, Alimentación y Medio Ambiente, Guía de Playas, 2015.

[11] Casal, G., Sánchez-Carnero, N. \& Freire, J., Generación de una línea de costa digital de Galicia (NW España) a gran escala, utilizando fotointerpretación y segmentación dinámica. Boletín de la Asociación de Geógrafos Españoles, 53, pp. 7-19, 2010.

[12] CUR, C.f.C.E.R., Codes Specifications Hydraulics, Delft, Manual on artificial beach nourishment: Centre for Civil Engineering Research, Codes and Specifications, 1987. 